\title{
Will Women Be Women? Analyzing the Gender Difference among Financial Experts
}

\author{
Daniela Beckmann and Lukas Menkhoff* \\ Discussion Paper No.391 \\ February 2008 \\ ISSN 0949-9962
}

\begin{abstract}
There are robust gender differences in the domains of risk taking, overconfidence and competition behavior. However, as expertise tends to level these differences, we ask whether financial experts still show gender dissimilarities in their domains of decision making? We analyze survey responses of 649 fund managers in the U.S., Germany, Italy and Thailand, and find that female fund managers tend to behave as expected from gender studies: they are more risk averse and shy away from competition in the tournament scenario. The expected lower degree of overconfidence by women is yet so small that it becomes insignificant in fund management.
\end{abstract}

JEL-Classification: J16 (economics of gender), G23 (funds), D8 (information, uncertainty) Key words: $\quad$ fund managers, gender differences, risk, overconfidence, tournament behavior

We very much appreciate the contributions made by the fund managers who were available for interviews and took time to respond to the survey. We thank the Investment Management Associations in Germany, Italy, and Thailand for the provision of indispensable recommendation letters. Furthermore, we are grateful to Torben Lütje, Michael Melvin, Luca Rebeggiani, Maik Schmeling and Ulrich Schmidt in helping us to conduct the survey and giving comments, and we thank two anonymous referees for their support. Last but not least, financial support by the Volkswagen Foundation is gratefully acknowledged.

* Daniela Beckmann, Lukas Menkhoff, Leibniz Universität Hannover, Department of Economics, Königsworther Platz 1, D-30167 Hannover, Germany, beckmann@ gif.unihannover.de, menkhoff@gif.uni-hannover.de 


\section{Will Women Be Women? Analyzing the Gender Difference among Financial Experts}

\section{INTRODUCTION}

We tend to have established stereotypes in mind when we think about the behavior of women and men. A prominent case is behavior towards risk, in which women are often seen as being more risk averse. Indeed, there are reams of carefully designed experiments which exactly detect risk-related gender dissimilarities and thus approve it as being fair to say that women are different from men in this respect (cf. Byrnes et al., 1999, Eckel and Grossman, 2006). While virtually all of these studies reflect students' behavior, it is reassuring that survey evidence from households confirms experimental findings (cf. e.g. Barsky et al., 1997, Donkers et al., 2001). However, groups of students and households may be representative for the population but not necessarily for those financial professionals who are experts in managing risks. As we know that familiarity with risk changes behavior towards the latter (cf. e.g. Slovic et al., 2000, Dwyer et al., 2002), the question emerges whether the change of focus from laymen to financial experts also impacts the gender difference. We therefore conduct a survey among professional fund managers which is the first for this group to analyze differences between women and men in their behavior towards risk.

Fund managers are not only worth a detailed analysis because they are experts in managing risks but also because they work in a field of financial decision making. There is some evidence that decisions in financial affairs may differ from decisions in abstract gambles, possibly because financial decisions involve clear incentives. This framing effect has been found in experiments and reduces the gender difference in risk aversion (cf. Schubert et al., 1999). Thus, there seem to be two separate forces which reduce the gender difference in risk aversion, i.e. familiarity with risk and risk decision under financial framing. Both forces apply to fund managers' business. Therefore, we expect that gender-specific behavior towards risk is overruled by the more uniform behavior of being a financial expert.

As this hypothesis of "expertise dominates gender" is not restricted to risk behavior alone, we also test it with respect to two further phenomena: (over)confidence and tournament behavior. Both are important for financial decision making, and women have been found to differ from their male counterparts: people are tentatively overconfident but women less than men (cf. e.g. Lenney, 1977, Lundeberg et al., 1992). Barber and Odean (2001) regard the stronger overconfidence of men as absolutely undisputed and thus use gender as a proxy for 
overconfidence in order to explain excessive, detrimental trading behavior. Successive studies have questioned, however, whether it is really male overconfidence that drives the outcome. Deaves et al. (2004) and Biais et al. (2005) confirm that overconfidence drives trading (and men trade relatively more) but do not find male students to be more overconfident in their miscalibration measures. There is thus some doubt as to whether male overconfidence is robust in financial affairs; indeed, it motivates one to extend evidence to financial experts-here fund managers-whose performance would be affected by excessive trading. Finally, there is emerging evidence that women "shy away from competition" to quote Niederle and Vesterlund (2007). This pattern has also been found for example by Gneezy et al. (2003) or Dohmen and Falk (2006). As it already seems to exist among young children (cf. Gneezy and Rustichini, 2004), the less competitive behavior of women may be seen as typical. However, this behavior stands in contrast to tournaments in the fund management industry (cf. Brown et al., 1996) where fund managers are publicly benchmarked and ranked. This contrast raises the question whether a gender difference shows up in the environment of fund management tournaments. ${ }^{1}$ Again, we are not yet aware of any evidence on gender-related differences in this field.

Despite this contrast between "shying away from competition" versus "welcoming tournaments", there is no general presumption that typical female behavior would be less efficient than male behavior. ${ }^{2}$ This also applies to higher risk aversion as fund managers do not aim for maximum returns but for risk-adjusted performance. It seems intriguing in this respect that the few studies analyzing gender-related performance among U.S. fund managers find that women achieve about the same risk-adjusted performance as their male colleagues (cf. Atkinson et al., 2003, Niessen and Ruenzi, 2006). ${ }^{3}$ If there are effects from the gender difference on performance they may go in both directions: some measures of risk aversion that we use indicate (more) distorted risk perception of women and would thus be a disadvantage to invest-

${ }^{1}$ It is perfectly possible that there is an ongoing self-selection mechanism among women on becoming fund managers. If so, this supports the hypothesis of "expertise dominates gender".

2 Interestingly, recent research indicates that women react on incentives-which are extremely strong in fund management - as men do (Paarsch and Shearer, 2007).

3 Unfortunately, Chevalier and Ellison (1999), who carefully analyze a large sample of fund managers, do not include a gender variable because they regard their $7 \%$-share of women as being too small. Atkinson et al. (2003) compare a sample of 70 women managing bonds to a matching sample of men. Niessen and Ruenzi (2006) rely on a share of female professionals in their sample of around $10 \%$, which equals approximately between 130 and 170 women over the whole sample period. Green et al. (2007) conclude that female analysts seem to do their job as well as men although they have a somewhat worse forecasting performance. Kumar (2007) detects female analysts to provide bolder forecasts but to be relatively more accurate. 
ment performance for female analysts, whereas less female overconfidence would probably benefit performance.

Our research on gender differences extends most former studies towards the realm of financial experts, here professional fund managers. As we search for information which is undistorted by (unobservable) legal, customer or company restrictions, we ask fund managers directly via a questionnaire survey. ${ }^{4}$ In this way, we obtain their version of risk behavior, overconfidence and tournament behavior and do not need to infer it from fund transactions, which also reflect the impact from legal restrictions or customer requirements. Accordingly, survey data are undistorted in this respect and thus provide useful evidence complementing transaction data. ${ }^{5}$ The survey approach has another important advantage by compiling the necessary data, including the above-mentioned three areas of gender differences-each of them addressed by specifically designed items - as well as a full set of relevant control variables. Finally, as we are interested in generally valid gender differences, we provide information on fund managers in four countries, i.e. the United States, Germany, Italy and Thailand. ${ }^{6}$ The resulting response from 649 fund managers, among them 125 women, yields one main finding.

Testing the "expertise dominates gender" hypothesis surprisingly ends in a victory for the gender difference. Whether we take descriptive statistics or control for a large set of competing influences, the gender variable always shows the sign as expected from the earlier literature, i.e. women will indeed be women even in the demanding environment of fund management. However, the economic importance of the gender difference varies. First, female fund managers keep their more risk averse behavior but on the other hand the effect is comparatively weak for the established risk measures. Second, we reject the view that women are less overconfident than men for the case of fund managers (although coefficients' signs hint at the expected direction). This finding is robust to an extension of three different measures of overconfidence, i.e. overoptimistic self-assessment, illusion of control and miscalibration. Third, evidence is consistent with the hypothesis that female fund managers shy away from

4 We only know of one study which analyzes some attitudes towards risk of US financial experts, mainly investment counselors, finding that these female professionals seem to be more risk averse than men (Olsen and Cox, 2001).

5 The conduct of a new survey is often the only way to get information. Examples include the survey of 139 compensation executives (Levine, 1993), the survey of 184 firms on reasons for wage rigidity (Campbell and Kamlani, 1997), the survey of 84 central banks on issues of credibility (Blinder, 2000) and the survey of 200 foreign exchange professionals on their time horizons in position taking (Menkhoff, 2001).

6 The selection of target countries is determined by achieving variety (Europe, the US and an emerging market) and by achieving reasonable response due to support from investment associations (see data section). 
competition. Fourth, the relative economic importance of the gender-related difference in explaining behavior is sometimes small in comparison to competing influences, indicating that indeed financial expertise decreases the gender difference-but does not erase it.

The remainder of the paper is organized as follows: Section II. describes the data set used. Section III. addresses risk behavior, while Section IV. focuses on overconfidence and Section V. on tournament behavior. Section VI. concludes.

\section{DATA}

The utilized data consists of a unique set of responses from 649 fund managers in four countries particularly compiled for our research.

We conducted the written survey with professional fund managers in the United States, Germany, Italy, and Thailand between spring 2003 and winter 2004. With the help of the respective investment association ${ }^{7}$ in three out of the four countries, we generated 649 valid questionnaires, where gender is split into 125 women and 524 men. Prior oral interviews in all four countries with fund managers of different hierarchies and of both sexes, previous test runs for clarity, and guaranteed anonymity were factors to ensure useful responses.

In order to check for representativeness of the country data sets generated, we compare assets under management covered by the surveyed firms with the market structure in total. Test results are shown in Table 1. In all four countries, we find that responses by and large reflect the market with respect to the representation of firm size.

Furthermore, Table 1 reveals firm participation rate, number of questionnaires and share of female participation for each country. Indeed, as fund managers sometimes passed questionnaires to colleagues, we cannot report response rates in terms of the distributed questionnaires. We know, however, that we generated a participation rate of $64.7 \%$ altogether at the company level. While participation among contacted firms was highest in Thailand with 93.5\% (29 of 31 contacted companies participated), it was relatively the lowest in the United States, where 74 out of 250 contacted companies responded (29.6\%). In absolute numbers, generated country samples cover between 112 questionnaires in Italy and 263 in Germany.

Regarding representation of gender, the global mutual fund industry can undoubtedly be seen as a male-dominated field. Nevertheless, the share of female respondents varies considerably among the four countries surveyed. While the U.S. and German samples comprise

\footnotetext{
${ }^{7}$ We received helpful support from the "Bundesverband Investment und Asset Management e.V.", in short: "BVI" for Germany, the "Associazione Italiana del Risparmio Gestito", in short: "Assogestioni" for Italy and the "Association of Investment Management Companies", in short "AIMC" for the Thai market. In the USA, Professor Michael Melvin, at that time at Arizona State University, supported this research.
} 
slightly over ten percent of female participants, in Italy one fifth of the surveyed managers are women, and in Thailand the sample is almost equally balanced. Indeed, taking the U.S. mutual fund industry on the one hand, female shares have constantly been around $10 \%$ within the last twelve years (cf. Chevalier and Ellison, 1999, Niessen and Ruenzi, 2006). In Thailand on the other hand, the fund managers interviewed highlighted that the female work force, in contrast to some other East Asian countries, has been comparably strong in banking and financial service sectors for decades and that several women have reached considerable influence in the financial industry. This is in line with the substantial female share in our sample.

In order to learn more about surveyed fund managers' characteristics, Table 2 provides descriptive statistics concerning their demographic, career and fund characteristics, split by gender and testing the significance of gender-related differences. Table 2 first presents four demographic characteristics, i.e. age, experience, marital status and education. The U.S. fund managers lead the others with respect to age and experience, probably matching the fund management industry's development in a cross-country comparison. We also find women to be younger and less experienced than their male counterparts in the U.S., Germany and Italy, with some statistically significant differences in the last two countries. In Thailand, however, we find our data corresponding to what fund managers told us during previous interviews: women are on average as old as their male colleagues and even significantly more experienced. While the minority of female fund managers are married, differing significantly from their male counterparts in Germany and Italy, the opposite holds only for the U.S., where it is the majority of (the comparatively older) fund managers of both sexes who are married. In terms of education, our sample discloses no significant gender difference in any country.

Turning to the three career characteristics, we find that women hold significantly lower positions than men in Germany and Italy, a fact which goes hand in hand with significantly lower personal assets under management and shorter working hours. In the U.S. and Thailand - by contrast - there is no gender difference observable in these three variables.

Finally, women do not really manage other fund types than men. Although they seem to work somewhat more often in mutual than in other funds, in equity more than in bond funds and in actively more than in passively managed funds, the gender difference is only significant in two cases. Moreover, this tendency only applies to the three Western countries and is rather reversed —although not to a statistically significant degree-in Thailand.

Taken together, for the U.S. and for Thailand, there are no significant gender differences revealed, while for the two other markets, female and male fund managers often differ significantly in their individual characteristics. Accordingly, women in our total sample tend 
to be younger, less experienced, less often married, work in lower positions, manage fewer assets, work fewer hours, more often manage mutual funds with a higher degree of active management.

Due to these marked differences-in individual characteristics and between countriesit appears crucial to control for these variables when analyzing the question of whether women will be women in terms of risk taking, overconfidence and tournament behavior.

\section{RISK BEHAVIOR}

Analyzing fund managers' behavior towards risk by applying three measures, we reveal women to behave more risk averse than men. This finding holds for comparisons between sexes for the single measures in each country as well as for multivariate regression evidence where countries are pooled and the gender variable is controlled by a set of determinants.

We start the analysis of gender differences among professional financial market players with a first direct measure of risk behavior, i.e. self-stated risk aversion, which has proved to be a most useful variable (cf. Kapteyn and Teppa, 2002). This survey measure has been validated in experiments and has thus proved that women are more risk averse (cf. Dohmen et al., 2005). As a second measure, we assess the degree of loss aversion as in particular modeled by Kahneman and Tversky's (1979) prospect theory; experimental work by Schmidt and Traub (2002) shows women to be more loss averse than men. Finally, we complement these generally established risk measures by including a questionnaire item on the empirically detected tendency of investors to hold losing stocks too long and sell winning stocks too early, the socalled disposition effect (cf. Shefrin and Statman, 1985). We regard the disposition effect as a kind of distorted risk aversion; Weber and Welfens (2006) do not find a significant gender difference for individual investors.

Table 3 shows the first results in the form of mean responses for both sexes and a test to discover whether there is gender homogeneity. Directly asked about risk taking in professional investment decisions, only in Italy women respond to act more risk averse than men to a statistically significant degree. Turning to loss aversion, we discover that women show a significantly higher loss aversion in Thailand. Furthermore, a notably higher number of women than men agree on their behavior being consistent with the disposition effect. As an intermediate summary, we can state that there is a tendency by female fund managers to behave more risk averse, as all significant results support this tendency (5 out of 12 cases). Interestingly, in terms of cross-country considerations, we reveal two significant gender differ- 
ences for the Italian and Thai market, only one different item for the German and none for the U.S. market.

So far, we have not controlled for fund managers' characteristics. These characteristics, however, do not only mediate gender differences, as previously described in studies such as Atkinson et al. (2003) for wealth and investment knowledge, or Sunden and Surrette (1998) in the case of marital status, but they have also been shown to exert significant influence on an individual's risk behavior itself (cf. e.g. Jianakoplos and Bernasek, 1998). In order to be on the safe side when analyzing gender impact, we use-in addition to marital status - the other variables introduced in Section 2 as controls: starting with demographic variables, Dohmen et al. (2005) detect willingness to take risk to increase corresponding to younger age levels (although Dwyer et al., 2002, do not find this effect). Graham (1999) finds that risk aversion decreases with experience of analysts (cf. Clement and Tse, 2005), which is tentatively confirmed by Menkhoff et al. (2006) for fund managers and by Dhar and Zhu (2007) for individual investors. Moreover, e.g. Dwyer et al. (2002) find that more educated investors tend to take more risk than their less educated counterparts. As our second group of variables, we use career proxies to capture the effect of wealth and knowledge on (more) risk taking which has been identified for individual investors (cf. Graham et al., 2006). In our analysis we thus control for a higher position, for more personal assets under management and for more working hours. The third group of control variables considers possible impacts from the type of fund managed: it has been hypothesized that mutual fund business may be more competitive than pension funds (Lakonishok et al., 1992) and it seems self-evident that fund managers may to some extent self-select into preferred fields. More risk-averse fund managers may thus prefer bonds over equities and passive over active management. Finally, as we pool the total sample of 649 cases, we have to include dummy variables to control for country-specific effects.

Results of the multivariate ordered probit regressions are given in Table 4. Overall, we find the gender variable to reveal significant explanatory power over two out of three risk behavior variables; gender is thus among the most important variables in our setting to understand risk aversion. Although controlling for the ten variables just discussed above, we reveal that female professionals behave consistently more risk averse than their male colleagues. ${ }^{8}$ In detail, directly questioned less risk averse investment behavior (column 1) is significantly lower for female fund managers (but more pronounced among higher positioned professionals managing less index-oriented bond funds). By contrast, a lower loss aversion (column 2) is not significantly different for female fund managers but determined by a few other variables,

\footnotetext{
${ }^{8}$ These results, as well as those reported later, are robust to the exclusion of different variables from
} the regressions. 
such as being married and having more assets under management. The disposition effect (column 3) is significantly smaller for male asset managers as well as for those with the relatively superior career characteristics of being in a higher position with more assets under their personal responsibility; the latter scenario indicates an efficient selection mechanism as more career success is related to less distorted decision making (moreover, managers in mutual funds and equity business express a lower disposition effect).

It seems noteworthy that risk behavior in this approach is not well understood by demographic characteristics, which makes the explanatory power of gender even more pronounced. Rather, a self-selection mechanism may be observed, because in particular equity managers and more successful managers—-proxied by position and assets under management—respond by being more willing to take risks. Finally, country dummies do not reveal much in the multivariate approach.

Overall, our primary attention is on the gender variable and this gives a clear result: female fund managers tend to show more risk averse behavior then their male counterparts (as it is also found in the general population), and a higher degree of the disposition effect, indicating distorted behavior towards risk. We now turn to the relation between overconfidence and gender.

\section{OVERCONFIDENCE}

We adopt three measures to address overconfidence and find that female fund managers do not differ significantly from their male colleagues.

Previous studies have shown that different measures of overconfidence are not necessarily correlated. ${ }^{9}$ Therefore, we choose to address all three forms of overconfidence independently, respectively covering a measure of the better-than-average effect, illusion of control, and miscalibration. In detail, we ask the surveyed professionals to self-assess their achievements in fund management compared to their peer group; we question them about their approval of the statement that published business news do not surprise them; and finally, taking into account that overconfident individuals have been found to miscalibrate by giving too narrow confidence intervals, we confront them with the task of $90 \%$ probability forecasts of their respective home market equity index for the following month. ${ }^{10}$ Again, as demonstrated in Section 3 on risk behavior, we first show comparisons between sexes for three measures in all the four countries surveyed and then give regression results on the pooled sample.

\footnotetext{
9 A thorough experimental assessment of different measures is given by Glaser et al. (2005). Neither they nor e.g. Deaves et al. (2004) and Oberlechner and Osler (2006) find positive correlations between e.g. miscalibraton and an overly positive self-assessment.

${ }^{10}$ Cf. e.g. Biais et al. (2005), Glaser et al. (2005) or Menkhoff et al. (2006) for using similar measures.
} 
Table 5 shows our findings, split by gender and with indications of statistical significance of a gender-related difference. Asked about their achievements relative to their peers, surveyed fund managers across all four countries and both sexes reveal on average overly positive self-assessments: while a value of four would indicate fund managers to be equally as good as their benchmark, surveyed professional groups show means between 2.7 and 3.3 and thus describe themselves on average to be better than their benchmark. Only in the case of Italy does the gender difference significantly show less overconfident female response. Addressing control illusion among professionals, we assume that more confident managers will experience lower surprise about upcoming news in financial markets. However, on average, we find that both women and men rather contradict the statement that "Most of the published business news does not surprise me at all", and we thus find neither any indication for this form of overconfidence, nor do we detect any significant gender difference. For the third type of overconfidence, miscalibration, a comparison between female and male professionals concerning estimated width of equity index ranges, calculated from maximum and minimum level estimations in relation to the actual index level, reveals overconfidence again: estimates neither include future realization in $90 \%$ of cases, nor does the given range seem wide enough when compared to a GARCH $(1,1)$ forecast. However, it is only in the German case that women are less overconfident than their male colleagues. To sum up, the gender difference is rarely significant, i.e. only in two out of 12 cases, although these two cases-as well as several signs_- point towards less overconfident female fund managers.

In order to control for the possible influence of personal characteristics, we choose the same set of control variables as before when moving towards the multivariate approach. Again, controlling for several factors is well justified by previous research and derived controversies: Bengtsson et al. (2005) or Deaves et al. (2004) confirm e.g. age to be a relevant factor in observed gender differences in their experimental work. While e.g. Gervais and Odean (2001) theoretically and Locke and Mann (2001) empirically argue that overconfidence is highest for inexperienced traders, experts have been found to be more likely than inexperienced subjects to show overconfident behavior (cf. e.g. Heath and Tversky, 1991 or Glaser et al., 2005). Moreover, Barber and Odean (2001) have highlighted the influence of marital status on their results, revealing differences to be greatest between single women and men. Finally, Estes and Hosseini (1988) reveal the significant role of education and familiarity - proxied by our career variables—-for confidence in investment decisions.

The multivariate estimation results are shown in Table 6 and confirm our previous finding from Table 5. To cut a long story short: we do not find the gender variable to significantly 
matter for any of the three overconfidence measures. Our findings are thus in line with the student experiments by Deaves et al. (2004) and Biais et al. (2005) and indicate that fund managers behave differently from the individual investors analyzed by Barber and Odean (2001). Further significant variables indicate that the self-assessment measure of overconfidence may also involve justified confidence as more experienced and harder working fund managers feel more successful. Moreover, the plausibility of our survey as well as the importance of control variables appears to be underlined by the last regression in Table 6: fund managers with a larger responsibility for assets under management indeed give broader-i.e. here better-equity index estimates. Country dummies do not give a clear pattern here.

Overall, we find some evidence in explaining overconfidence but women are rarely significantly different from men in the 12 comparisons in Table 5 and the gender variable is never significant in the three regressions shown in Table 6.

The third part of our analysis sheds light on a possible gender difference in fund managers' competition behavior in a tournament situation.

\section{TOURNAMENT BEHAVIOR}

Regarding tournament behavior, we confront fund managers with two different realistic scenarios and subsequently find women to behave differently from men. Indeed, women are found to change their strategy more often when they are ahead of or behind the market- they try to perform closer to the market development than men.

We translate the literature's finding that women are more likely than men to shy away from competition into tournament situations which often happen near the end of the investment period (cf. Brown et al., 1996). In these situations, fund managers are aware of the opportunity, on the one hand, to receive disproportionately high new cash flows into "their" fund for extraordinary performance (cf. Sirri and Tufano, 1998). Seeking such performance requires deviating from the market benchmark. On the other hand, bad investment decisions-i.e. performance below the market-are punished with negative career consequences (cf. Chevalier and Ellison, 1999). In the survey, we give two scenarios: either achieved success in outperforming the benchmark or underperformance near the end of the valuation period.

In both scenarios-out- or underperformance-fund managers face a two-stage decision. First, they could stick to their earlier investment strategy, which should actually be the one derived from their (private) information. The only new piece of information that is going to be considered here is their fund's position relative to the benchmark. This information 
might motivate them to change their strategy. Then there is a second decision to be made: in the case of outperformance, professionals could either intend to "lock in" their achieved outperformance or even aggressively welcome competition by increasing the risk level in order to become top performer. In the second case, underperforming their benchmark might lead them to try to guard a chance at "catching up" relative to their benchmark or to decrease the risk level in order to save them from further hurtful performance losses.

Former mutual fund studies do not provide undisputed expectations on fund managers' behavior in such tournaments (e.g. Busse, 2001, Goriaev et al., 2005). From a gender perspective, however, the less competitive behavior of women (Gupta et al., 2005, Dohmen and Falk, 2006) may imply a stronger orientation towards the benchmark and less competition seeking by sticking to their preferred strategy (which obviously deviates from the benchmark). This expectation concerning women's behavior is consistent with the finding that U.S. female fund managers show very good or very bad performance ranks less often than men (Niessen and Ruenzi, 2006).

Starting with the scenario of outperformance, Table 7 shows female professionals in Italy and Thailand to be significantly more likely than their male colleagues to change instead of keeping their previous strategy. Indeed, they predominantly $(55.2 \%$ in Thailand and even $81.8 \%$ in Italy) "lock in" achieved outperformance. When we look at the "second" decisionthat is the direction of riskiness conditional on change-only a very limited number ${ }^{11}$ of professionals chooses an increase in the risk level.

Turning to the second scenario-previous underperformance-we disclose once more that women are more likely to vary the risk level than men. This time, findings tend to be consistent across all four countries, although only being significant for Thailand. Concerning the second decision, whether to increase or decrease riskiness in the future, we reveal interesting findings: women are more prone than men to increasing the relative risk level, with statistical significance for Germany (where $20.8 \%$ of surveyed female fund managers increase risk) and Thailand (with as high as $58.6 \%$ of women doing so). Women's willingness to increase risk may seem surprising at first sight, but is consistent with a strong ambition to stick close to the benchmark's performance. Concerning a decrease in risk level, gender evidence is mixed, with a few U.S. female professionals $(11.8 \%$ compared to only $3.1 \%$ of their male counterparts) significantly preferring this behavior.

As in the previous sections, we test the impact of gender in a multivariate approachhere a binary probit model—controlling for the usual set of variables. Table 8 shows that our

\footnotetext{
${ }^{11}$ We refrain from integrating this specific scenario in following multivariate regressions as the number of observations is too small for meaningful estimations.
} 
findings on gender differences also hold in the extended framework. Gender is the only variable to consistently explain the first decision to be made as women more often change their strategy in both scenarios. Looking at the second decision, i.e. the sign of change, women consistently decrease the risk level in the outperformance scenario. When confronted with underperformance near the end of the valuation period, women are significantly more likely to increase the risk level. Only in terms of a risk level decrease is the gender variable not significant. Besides, significant country variables reinforce effects in Germany, Thailand and Italy in comparison to the United States.

Overall, female fund managers seem to confirm the kind of competitive behavior which is found among women in general, i.e. they shy away from competition in the assumed tournament scenarios more often than men.

\section{CONCLUSIONS}

The question whether women behave differently from men has been extensively researched and reveals robust gender differences. Women are significantly more risk averse, tend to be less overconfident and behave less competitively oriented. Thus, women behave differently in these three domains, which are highly important in the financial industry as risk taking, confident decision making and tough competition are part of fund managers' jobs. Moreover, we know that expertise in a certain field tends to level the gender difference. We thus get a most interesting setting: do we reject in our sample of financial experts the gender difference as it is usually found in the three domains of risk taking, overconfidence and competition behavior? In short, does expertise dominate gender?

We address this question head on by providing fresh evidence. What is most interesting is that our survey covers fund managers, thus extending beyond students or individual investors, who are usually considered. Moreover, the survey covers four countries, i.e. the U.S., Germany, Italy and Thailand. From a methodological point of view it has two advantages: first, the answers reflect the fact that the respondents' opinions are undistorted by restrictions that co-determine their observable investment behavior. Second, the survey approach allows controlling for a large set of variables that have been revealed to be potentially relevant in earlier studies.

We find that fund managing women will be women in their profession: they are more risk averse and shy away from competition in the tournament. Regarding the lesser overconfidence of women found in most cases, however, the gender difference is so weak in fund management that it becomes insignificant in the regression approach. 
Although the overall outcome of obviously existing gender differences in behavior could have been expected from former gender studies, it is nonetheless surprising when evaluated from the studies focusing on experts' behavior. To summarize, we thus conclude a rejection of the "expertise dominates gender" hypothesis for our sample.

The persistence of gender differences in investment-related behavior may raise concerns as to whether this is compatible with market efficiency. What we can say on this issue is, indeed, that our analysis does not provide any indication that women may be less successful as fund managers than men: a different risk aversion is mediated by the convention in fund management to focus on risk-adjusted returns. Women's tendency in tournaments to change their position more than men towards the market may lead to less extreme outcomes but does not imply lower returns (cf. Nissen and Ruenzi, 2006). Finally, less overconfidence of womeneven if insignificant—will hardly deteriorate performance.

So the discovery of systematic differences in behavior-in combination with equal performance-stimulates thoughts about consequences for the industry: female fund managers may be better suited to female customers who share their pattern in behavior than do men and female fund managers may possess a greater ability to exercise certain investment styles than their male colleagues. 


\section{REFERENCES}

Atkinson, Stanley M., Samantha Boyce Baird and Melissa B. Frye (2003). Do Female Mutual Fund Managers Manage Differently, Journal of Financial Research. 26(1): 1-18.

Barber, Brad M. and Terrance Odean (2001). Boys Will Be Boys: Gender, Overconfidence, and Common Stock Investment, Quarterly Journal of Economics. 116(1): 261-292.

Barsky, Robert B., Thomas F. Juster, Miles S. Kimball and Matthew D. Shapiro (1997). Preference Parameters and Behavioral Heterogeneity: An Experimental Approach in the Health and Retirement Study, Quarterly Journal of Economics. 112(2): 537-579.

Bengtsson, Claes, Mats Persson, and Peter Willenhag (2005). Gender and Overconfidence, Economics Letters. 86(2): 199-203.

Biais, Bruno, Denis Hilton, and Karine Mazurier (2005). Judgemental Overconfidence, SelfMonitoring, and Trading Performance in an Experimental Financial Market, Review of Economic Studies. 72(2): 287-312.

Blinder, Alan S. (2000). Central-Bank Credibility: Why Do We Care? How Do We Build It?, American Economic Review. 90(5): 1421-1431.

Brown, Keith C., W. Van Harlow and Laura T. Starks (1996). Of Tournaments and Temptations: An Analysis of Managerial Incentives in the Mutual Fund Industry, Journal of Finance. 51(1): 85-110.

Busse, Jeffrey A. (2001). Another Look at Mutual Fund Tournaments, Journal of Financial and Quantitative Analysis. 36(1): 53-73.

Byrnes, James P., David C. Miller and William D. Schafer (1999). Gender Differences in Risk-Taking: A Meta-Analysis, Psychological Bulletin. 125(3): 367-383.

Campbell III, Carl M. and Kunal S. Kamlani (1997). The Reasons for Wage Rigidity: Evidence from a Survey of Firms, Quarterly Journal of Economics. 112(3): 759-789.

Chevalier, Judith und Glenn Ellison (1999). Career Concerns of Mutual Fund Managers, Quarterly Journal of Economics. 114(2): 389-432.

Clement, Michael B. and Senyo Y. Tse (2005). Financial Analyst Characteristics and Herding Behavior in Forecasting, Journal of Finance. 60(1): 307-341.

Dhar, Ravi and Ning Zhu (2006). Up, Close and Personal: An Individual Level Analysis of the Disposition Effect, Management Science. 52(5): 726-740.

Deaves, Richard, Erik Lüders, and Guo Ying Luo (2004). An Experimental Test of the Impact of Overconfidence and Gender on Trading Activity, Working Paper, Center for European Economic Research (ZEW) and Rutgers University.

Dohmen, Thomas and Armin Falk (2006). Performance, Pay and Multi-Dimensional Sorting: Productivity, Preferences and Gender, IZA Discussion Paper No. 2001, Bonn.

Dohmen, Thomas, Armin Falk, David Huffman, Uwe Sunde, Jürgen Schupp, Gert G. Wagner (2005). Individual Risk Attitudes, New Evidence from Large, Representative, Experimentally-Validated Survey, IZA Discussion Paper, No. 1730, Bonn.

Donkers, Bas, Bertrand Melenberg, and Arthur van Soest (2001). Estimating Risk Attitudes Using Lotteries: A Large Sample Approach, Journal of Risk and Uncertainty. 22(2): 165-195.

Dwyer, Peggy D., James H. Gilkeson, and John A. List (2002). Gender Differences in Revealed Risk Taking: Evidence from Mutual Fund Investors, Economics Letters. 76(2): 151-158.

Eckel, Catherine C. and Philip J. Grossman (2006). Men, Women and Risk Aversion: Experimental Evidence, in: Plott, Charles R., and Vernon L. Smith (eds.), Handbook of Experimental Economics Results. New York, forthcoming.

Estes, Ralph and Jinoos Hosseini (1988). The Gender Gap on Wall Street: An Empirical Analysis of Confidence in Investment Decision Making, Journal of Psychology. 122(6): 577-590. 
Gervais, Simon and Terrance Odean (2001). Learning to be Overconfident, Review of Financial Studies. 14(1): 1-27.

Glaser, Markus, Thomas Langer and Martin Weber (2005). Overconfidence of Professionals and Lay Men: Individual Differences Within and Between Tasks, Sonderforschungsbereich 504 Publications No. 05-25, University of Mannheim.

Gneezy, Uri, Muriel Niederle and Aldo Rustichini (2003). Performance in Competitive Environments: Gender Differences, Quarterly Journal of Economics. 118(3): 1049-1074.

Gneezy, Uri and Aldo Rustichini (2004). Gender and Competition at a Young Age, American Economic Review. 89(2): 386-391.

Goriaev, Alexei P., Theo E. Nijman and Bas J. M. Werker (2005). Yet Another Look at Mutual Fund Tournaments, Journal of Empirical Finance. 12(1): 127-137.

Graham, John R. (1999). Herding Among Investment Newsletters: Theory and Evidence, Journal of Finance. 54(1): 237-268.

Graham, John R., Campbell R. Harvey and Hai Huang (2006). Investor Competence, Trading Frequency, and Home Bias, AFA 2006 Boston Meetings Paper.

Green, T. Clifton, Narasimhan Jegadeesh and Yue Tang (2007). Gender and Job Performance: Evidence from Wall Street, NBER Working Paper 12897.

Gupta, Nabanita D., Anders Poulsen and Marie-Claire Villeval (2005). Male and Female Competitive Behavior - Experimental Evidence, CNRS Working Paper No. 05-12, Ecully.

Heath, Chip and Amos Tversky (1991). Preferences and Belief: Ambiguity and Competence in Choice under Uncertainty, Journal of Risk and Uncertainty. 4(1): 5-28.

Jianakoplos, Nancy A. and Alexandra Bernasek (1998). Are Women More Risk Averse?, Economic Inquiry. 36(4): 620-630.

Kahneman, Daniel and Amos Tversky (1979). Prospect Theory: An Analysis of Decision Under Risk, Econometrica. 47(2): 263-291.

Kapteyn, Arie and Federica Teppa (2002). Subjective Measures of Risk Aversion and Portfolio Choice, Center for Economic Research Discussion Paper No. 11, Tilburg University.

Kumar, Alok (2007). Do Social Biases Influence Market's Interpretation of New Public Information?, Working Paper, University of Texas at Austin.

Lakonishok, Josef, Andrei Shleifer and Robert W. Vishny (1992). The Structure and Performance of the Money Management Industry, Brookings Papers on Economic Activity, Microeconomics. 339-391.

Lenney, Ellen (1977). Women's Self-Confidence in Achievement Settings, Psychological Bulletin. 84(1): 1-13.

Levine, David I. (1993). Fairness, Markets, and Ability to Pay: Evidence from Compensation Executives, American Economic Review. 83(5): 1241-1259.

Locke, Peter R. and Steven C. Mann (2001). House Money and Overconfidence on the Trading Floor, Working Paper, George Washington University.

Lundeberg, Mary A., Paul W. Fox and Judith Punccohar (1992). Highly Confident but Wrong, Gender Differences and Similarities in Confidence Judgments, Journal of Educational Psychology. 86(1): 114-121.

Menkhoff, Lukas (2001). Short-Term Horizons in Foreign Exchange? Survey Evidence from Dealers and Fund Managers, Kyklos. 54(1): 27-47.

Menkhoff, Lukas, Ulrich Schmidt and Torsten Brozynski (2006). The Impact of Experience on Risk Taking, Overconfidence, and Herding of Fund Managers: Complementary Survey Evidence, European Economic Review. 50(7): 1753-1766.

Niederle, Muriel, and Lise Vesterlund (2007). Do Women Shy Away from Competition? Do Men Comepete Too Much?, Quarterly Journal of Economics. 122(3): 1067-1101.

Niessen, Alexandra and Stefan Ruenzi (2006). Sex Matters: Gender and Mutual Funds, $C F R$ Working Paper No. 06-01, University of Cologne 
Oberlechner, Thomas and Carol Osler (2006). Overconfidence in Currency Markets, Working Paper, Brandeis University.

Olsen, Robert A. and Constance M. Cox (2001). The Influence of Gender on the Perception and Response to Investment Risk: The Case of Professional Investors, Journal of Behavioral Finance. 2(1): 29-36.

Paarsch, Harry J. and Bruce S. Shearer (2007). Do Women React Differently to Incentives? Evidence from Experimental Data and Payroll Records, European Economic Review. 51(7): 1682-1707.

Schmidt, Ulrich and Stefan Traub (2002). An Experimental Test of Loss Aversion, Journal of Risk and Uncertainty. 25(3): 233-249.

Schubert, Renate, Martin Brown, Matthias Gysler and Hans Wolfgang Brachinger (1999). Financial Decision-Making: Are Women Really More Risk-Averse?, American Economic Review. 89(2): 381-385.

Shefrin, Hersh and Statman, Meir (1985). The Disposition to Sell Winners Too Early and Ride Losers Too Long: Theory and Evidence, Journal of Finance. 40(3): 777-790.

Sirri, Erik R. and Peter Tufano (1998). Costly Search and Mutual Fund Flows, Journal of Finance. 53(5): 1589-1622.

Slovic, Paul, B. Fischhoff, and S. Lichtenstein (2000). Facts and Fears: Understanding Perceived Risk, in: Slovic, Paul (ed.), The Perception of Risk. London: Earthscan/James \& James: 137-153.

Sunden, Annika E. and Brian J. Surette (1998). Gender Differences in the Allocation of Assets in Retirement Savings Plans, American Economic Review. 88(2): 207-211.

Weber, Martin and Frank Welfens (2006). An Individual Level Analysis of the Disposition Effect: Empirical and Experimental Evidence, Working Paper, University of Mannheim. 


\begin{tabular}{|c|c|c|c|c|}
\hline & \multicolumn{4}{|c|}{$\begin{array}{l}\text { Structure of the asset management industry } \\
\text { in relation to respective country sub sample } \\
\text { (assets under management) }\end{array}$} \\
\hline & USA & GER & ITA & THA \\
\hline $\mathrm{H}_{0}:$ no difference ${ }^{2}$ & $\begin{array}{l}-1.213 \\
(0.225)\end{array}$ & $\begin{array}{c}-0.669 \\
(0.503)\end{array}$ & $\begin{array}{c}-0.403 \\
(0.687)\end{array}$ & $\begin{array}{l}-0.136 \\
(0.892\end{array}$ \\
\hline Firm participation rate & $29.6 \%$ & $77.3 \%$ & $58.2 \%$ & $93.5 \%$ \\
\hline Number of questionnaires & 148 & 263 & 112 & 126 \\
\hline Share of female participants & $11.4 \%$ & $10.0 \%$ & $21.1 \%$ & $46.4 \%$ \\
\hline
\end{tabular}

1 The U.S. market data is taken from the 'Pensions \& Investments' money managers directory 2003 (www.pionline.com). For Germany, we use market data from the annual report 2003 of the BVI. The Italian market data for 2004/2005 is taken from the Italian Investment Management Association's Website "Assogestioni". Thailand data for 2004 emanates from a market share datasheet provided by the Thai Association of Investment Management Companies “AIMC" as well as selected companies' information.

2 The table gives the $\mathrm{z}$-value of the respective Mann-Whitney U test with the p-value in parentheses. 


\begin{tabular}{|c|c|c|c|c|}
\hline \multirow{2}{*}{$\begin{array}{l}\text { Characteristics } \\
\text { split by country } \\
\text { and gender }\end{array}$} & \multicolumn{4}{|c|}{$\mathrm{H}_{0}:$ no gender difference ${ }^{1}$} \\
\hline & USA & GER & ITA & $\begin{array}{c}\text { THA } \\
0\end{array}$ \\
\hline \multicolumn{5}{|c|}{ Demographic characteristics } \\
\hline $\mathrm{Age}^{2}$ in years & $\begin{array}{c}\sim 42 \sim 40 \\
-1.263(0.206)\end{array}$ & $\begin{array}{c}\sim 36 \sim 34 \\
\mathbf{- 2 . 0 0 2} * * *(\mathbf{0 . 0 4 5})\end{array}$ & $\begin{array}{c}\sim 37 \sim 32 \\
\mathbf{- 3 . 1 1 5} * * *(\mathbf{0 . 0 0 2})\end{array}$ & $\begin{array}{c}\sim 35 \sim 35 \\
-0.527(0.598)\end{array}$ \\
\hline $\begin{array}{l}\text { Experience }^{2} \\
\text { in years }\end{array}$ & $\begin{array}{cc}\sim 13 & \sim 12 \\
-1.008 & (0.313)\end{array}$ & $\begin{array}{cc}\sim 7 & \sim 6 \\
-1.386 & (0.166)\end{array}$ & $\begin{array}{c}\sim 9 \sim 6 \\
\mathbf{- 2 . 0 9 8}^{* *}(\mathbf{( 0 . 0 3 6 )}\end{array}$ & $\begin{array}{c}\sim 6 \sim 8 \\
-\mathbf{2 . 1 1 0} * *(\mathbf{0 . 0 3 5})\end{array}$ \\
\hline Married $^{3}$ in $\%$ & $\begin{array}{cc}82.5 & 82.4 \\
-0.039 & (0.969)\end{array}$ & $\begin{array}{cc}57.9 & 37.5 \\
-\mathbf{1 . 8 1 6} *(\mathbf{0 . 0 6 9})\end{array}$ & $\begin{array}{cc}57.1 & 36.4 \\
\mathbf{- 2 . 1 7 3} * *(\mathbf{0 . 0 3 0})\end{array}$ & $\begin{array}{cc}47.9 & 38.6 \\
-0.783 & (0.434)\end{array}$ \\
\hline $\begin{array}{l}\text { Academic } \\
\text { education }^{3} \text { in } \%\end{array}$ & $\begin{array}{cc}80.3 & 93.8 \\
-1.308 & (0.191)\end{array}$ & $\begin{array}{cc}86.5 & 88.0 \\
-0.206 & (0.837)\end{array}$ & $\begin{array}{rr}91.7 & 100.0 \\
-1.394 & (0.163)\end{array}$ & $\begin{array}{cc}95.5 & 96.6 \\
-0.292 & (0.771)\end{array}$ \\
\hline \multicolumn{5}{|c|}{ Career characteristics } \\
\hline Position $^{4}$ & $\begin{array}{cc}2.43 & 2.24 \\
-0.636 & (0.525)\end{array}$ & $\begin{array}{cc}2.01 & 1.46 \\
\mathbf{- 3 . 1 7 2} * * * *(\mathbf{0 . 0 0 2})\end{array}$ & $\begin{array}{cc}2.63 & 2.00 \\
\mathbf{- 2 . 3 9 8} * * & (\mathbf{0 . 0 1 7})\end{array}$ & $\begin{array}{cc}1.82 & 1.84 \\
-0.536 & (0.592)\end{array}$ \\
\hline Personal AuM ${ }^{5}$ & $\begin{array}{cc}4.00 & 3.60 \\
-0.843 & (0.399)\end{array}$ & $\begin{array}{cc}3.52 & 2.45 \\
\mathbf{- 3 . 3 3 2} * * *(\mathbf{0 . 0 0 1})\end{array}$ & $\begin{array}{cc}3.56 & 2.15 \\
\mathbf{- 4 . 1 7 0} * * * & (\mathbf{0 . 0 0 0})\end{array}$ & $\begin{array}{cc}3.16 & 3.18 \\
-0.070 & (0.944)\end{array}$ \\
\hline Working hours ${ }^{6}$ & $\begin{array}{cc}\sim 52 & \sim 51 \\
-1.097(0.273)\end{array}$ & $\begin{array}{c}\sim 50 \sim 47 \\
\mathbf{- 1 . 8 1 1} *(\mathbf{0 . 0 7 0})\end{array}$ & $\begin{array}{cc}\sim 49 & \sim 47 \\
\mathbf{- 2 . 0 3 5} * *(\mathbf{0 . 0 4 2})\end{array}$ & $\begin{array}{c}\sim 46 \sim 45 \\
0.928(0.354)\end{array}$ \\
\hline \multicolumn{5}{|c|}{ Fund characteristics } \\
\hline Type of fund ${ }^{7}$ & $\begin{array}{cc}2.16 & 1.82 \\
-1.555 & (0.120)\end{array}$ & $\begin{array}{cl}2.23 & 1.88 \\
\mathbf{- 1 . 8 8 3} & (\mathbf{0 . 0 6 0})\end{array}$ & $\begin{array}{rr}1.50 & 1.17 \\
-1.501(0.133)\end{array}$ & $\begin{array}{cc}2.00 & 2.11 \\
-0.750 & (0.453)\end{array}$ \\
\hline $\begin{array}{l}\text { Investment } \\
\text { Segment }^{8}\end{array}$ & $\begin{array}{cc}1.75 & 1.59 \\
-0.667 & (0.505)\end{array}$ & $\begin{array}{cc}1.56 & 1.48 \\
-0.664 & (0.507)\end{array}$ & $\begin{array}{rr}2.02 & 1.65 \\
-1.567 & (0.117)\end{array}$ & $\begin{array}{cc}2.02 & 2.20 \\
-1.083 & (0.279)\end{array}$ \\
\hline $\begin{array}{l}\text { Allowed } \\
\text { tracking error }^{9}\end{array}$ & $\begin{array}{cc}2.74 & 2.41 \\
-0.946 & (0.344)\end{array}$ & $\begin{array}{cc}2.73 & 2.70 \\
-0.271 & (0.786)\end{array}$ & $\begin{array}{cc}2.81 & 2.35 \\
\mathbf{- 1 . 7 3 1} & (\mathbf{0 . 0 8 3})\end{array}$ & $\begin{array}{cc}3.12 & 3.12 \\
-0.413 & (0.679)\end{array}$ \\
\hline $\begin{array}{l}\text { The table gives } \\
\text { the respective } \\
\text { The p-value is } \\
\text { Mean age and } \\
1=<4 \text { years of } \\
\text { Marital status } \\
3=\text { married, edu } \\
\text { Position ranges } \\
\text { Assets under p } \\
\text { (lowest) to } 6 \text { (h } \\
\text { Working hours } \\
\text { Type of fund i } \\
\text { provident, restr } \\
\text { For the investn } \\
\text { funds. Codings } \\
\text { The allowed tr }\end{array}$ & $\begin{array}{l}\text { mean value for } \mathrm{m} \\
\mathrm{n} \text {-Whitney U test } \\
\mathrm{n} \text { in parentheses. A } \\
\text { rience are derive } \\
\text { ience, respectivel } \\
\text { education are bi } \\
\mathrm{n} \text { is divided into } 1 \\
\mathrm{n} 1=\text { junior asset } \mathrm{m} \\
\text { al responsibility / } \\
\text { st) with amounts } \mathrm{t} \\
\text { assessed by six res } \\
\text { ssified by } 1=\text { mut } \\
\text { /private fund. } \\
\text { segment we split }\end{array}$ & $\begin{array}{l}\text { and female asset ma } \\
\text { garding gender specif } \\
\text { risks refer to level of } \\
\text { rom six response cat } \\
\text { o } 6=>\text { older than } 50 \text { y } \\
\text { ry variables. While } \\
\text { on-academic and } 3=a \\
\text { ager, over } 2=\text { senior, } 3 \\
\text { anagement (AuM) ar } \\
\text { are country specifica } \\
\text { nse categories rangin } \\
\text { fund, } 2=\text { both mutua } \\
\text { quity fund managem } \\
\text { quities and bonds/mol } \\
\text { is follows: "How acti }\end{array}$ & $\begin{array}{l}\text { gers in comparison as } \\
\text { differences in the fol } \\
\text { gnificance: } * 10 \%, * * \\
\text { ories that range from } \\
\text { s, and } 6=\text { more than } 1 \\
\text { arital status is classi } \\
\text { demic. } \\
\text { head of team to } 4=\mathrm{CIC} \\
\text { lassified into six resp } \\
\text { adopted. } \\
\text { rom } 1=<41 \text { hours to } 6 \\
\text { nd other funds, } 3=\text { oth } \\
\text { from the one of bo }\end{array}$ & $\begin{array}{l}\text { ell as the z-value of } \\
\text { displayed countries. } \\
\%, * * * 1 \% \text {. } \\
=<31 \text { years old, and } \\
\text { ears of experience. } \\
d \text { by } 1=\text { single and } \\
\text { EO. } \\
\text { se categories from } 1 \\
60 \text { hours. } \\
\text { funds, i.e. pension/ } \\
\text { and money market } \\
\text { oney market. } \\
\text { or) can you manage } \\
\text { exing. }\end{array}$ \\
\hline
\end{tabular}


[A] "In respect of professional investment decisions, I mostly act..."; six response categories ranging from $1=$ very risk averse to $6=$ little risk averse.

[B] "In case of loss positions in my portfolio I generally wait for a price rebound instead of selling those securities." Six response categories, ranging from $1=$ complete approval to $6=$ complete contradiction.

[C] "I prefer to take profits instead of cutting losses, when I am confronted with unexpected liquiddity demands." Six response categories, ranging from $1=$ complete approval to $6=$ complete contradiction.

\begin{tabular}{|c|c|c|c|c|c|}
\hline \multirow{2}{*}{\multicolumn{2}{|c|}{$\begin{array}{l}\text { Asset managers' } \\
\text { risk behavior }\end{array}$}} & \multicolumn{4}{|c|}{$\mathrm{H}_{\mathrm{o}}:$ no gender difference ${ }^{1}$} \\
\hline & & $\begin{array}{l}\text { USA } \\
0 \quad q\end{array}$ & $\begin{array}{l}\text { GER } \\
0 \quad \text { o }\end{array}$ & $\begin{array}{l}\text { ITA } \\
\begin{array}{ll}1 & 9 \\
0 & +\end{array}\end{array}$ & $\begin{array}{l}\text { THA } \\
0^{\lambda}+\end{array}$ \\
\hline [A] & Risk taking & $\begin{array}{cc}3.55 & 3.59 \\
-0.139 & (0.890)\end{array}$ & $\begin{array}{cc}3.50 & 3.50 \\
-0.070 & (0.944)\end{array}$ & $\begin{array}{cc}3.63 & 3.25 \\
\mathbf{- 1 . 6 7 1} & (\mathbf{0 . 0 9 5})\end{array}$ & $\begin{array}{rr}3.30 & 3.05 \\
-1.451 & (0.147)\end{array}$ \\
\hline [B] & Loss aversion & $\begin{array}{cc}4.18 & 4.47 \\
-0.925 & (0.355)\end{array}$ & $\begin{array}{cc}4.58 & 4.39 \\
-0.790 & (0.430)\end{array}$ & $\begin{array}{cc}4.29 & 4.05 \\
-0.640 & (0.522)\end{array}$ & $\begin{array}{c}3.83 \\
\mathbf{- 1 . 9 5 3} *(\mathbf{0 . 0 5 1})\end{array}$ \\
\hline [C] & $\begin{array}{l}\text { Disposition } \\
\text { effect }\end{array}$ & $\begin{array}{cc}3.82 & 3.53 \\
-0.856 & (0.392)\end{array}$ & $\begin{array}{cl}4.22 & 3.54 \\
\mathbf{- 2 . 0 4 3} * *(\mathbf{0 . 0 4 1})\end{array}$ & $\begin{array}{cc}3.96 & 3.35 \\
\mathbf{- 1 . 6 6 7} *(\mathbf{0 . 0 9 5})\end{array}$ & $\begin{array}{c}3.312 .90 \\
-\mathbf{1 . 7 1 6} *(\mathbf{0 . 0 8 6})\end{array}$ \\
\hline
\end{tabular}

$1 \quad$ The table gives the mean value for male and female asset managers in comparison as well as the z-value of the respective Mann-Whitney U test regarding gender specific differences in the four displayed countries. The $\mathrm{p}$-value is given in parentheses. Asterisks refer to level of significance: * 10\%, ** 5\%, *** $1 \%$.

\section{TABLE 4. Risk behavior in a multivariate framework}

\begin{tabular}{|c|c|c|c|c|c|c|}
\hline \multirow[b]{2}{*}{ Female } & \multicolumn{2}{|c|}{$\begin{array}{c}\text { Lower } \\
\text { risk aversion }\end{array}$} & \multicolumn{2}{|c|}{$\begin{array}{c}\text { Lower } \\
\text { loss aversion }\end{array}$} & \multicolumn{2}{|c|}{$\begin{array}{c}\text { Smaller } \\
\text { disposition effect }\end{array}$} \\
\hline & $-0.127 *$ & $(0.074)$ & -0.062 & $(0.376)$ & $-0.172 * *$ & $(0.014)$ \\
\hline Older & -0.104 & $(0.133)$ & -0.010 & $(0.881)$ & 0.031 & $(0.643)$ \\
\hline More experienced & -0.001 & $(0.990)$ & -0.046 & $(0.413)$ & -0.042 & $(0.458)$ \\
\hline Married & 0.004 & $(0.941)$ & $0.186 * * *$ & $(0.002)$ & 0.080 & $(0.178)$ \\
\hline Better educated & -0.055 & $(0.535)$ & 0.055 & $(0.524)$ & 0.093 & $(0.280)$ \\
\hline Higher position & $0.158 *$ & $(0.061)$ & 0.078 & $(0.359)$ & $0.216 * *$ & $(\mathbf{0 . 0 1 0})$ \\
\hline More personal AuM & -0.011 & $(0.802)$ & $0.144 * * *$ & $(0.001)$ & $0.122 * * *$ & $(\mathbf{0 . 0 0 5})$ \\
\hline More working hours & 0.011 & $(0.836)$ & 0.018 & $(0.731)$ & 0.039 & $(0.445)$ \\
\hline Other than mutual fund type & 0.031 & $(0.618)$ & -0.023 & $(0.704)$ & $-0.122 * *$ & $(0.047)$ \\
\hline Rather bond investment fund & $-0.127 * *$ & $(\mathbf{0 . 0 3 4})$ & -0.070 & $(0.237)$ & $-0.219 * * *$ & $(\mathbf{0 . 0 0 0})$ \\
\hline Lower tracking error allowed & $-0.219 * * *$ & $(0.000)$ & 0.036 & $(0.430)$ & 0.023 & $(0.611)$ \\
\hline Dummy GER & -0.182 & $(0.227)$ & $0.358 * *$ & $(0.015)$ & $0.340 * *$ & $(\mathbf{0 . 0 2 1})$ \\
\hline Dummy ITA & -0.029 & $(0.890)$ & 0.053 & $(0.796)$ & 0.066 & $(0.746)$ \\
\hline Dummy THA & -0.098 & $(0.600)$ & -0.303 & $(0.101)$ & -0.117 & $(0.524)$ \\
\hline $\begin{array}{l}\text { LR statistic } \\
\text { (Pseudo-)R }\end{array}$ & 0.04 & & $63.61 * * *$ & 0.05 & \multicolumn{2}{|c|}{0.06} \\
\hline
\end{tabular}

1 The table gives the coefficients of the ordered PROBIT regressions with p-values in parentheses. Asterisks refer to level of significance: * $10 \%, * * 5 \%, * * * 1 \%$. Explanations of the three dependent variables can be found in Table 3, information about the control variables is given in Table 2. Country dummies for Germany, Italy and Thailand are binary coded. 


\section{TABLE 5. Overconfidence and gender}

[A] Unrealistically positive self-evaluation is tested as follows: "How do you assess your achievement in asset management - compared to other asset managers' achievement in the same investment segment?" Response categories range from $1=$ much better to $7=$ much worse.

[B] Control illusion is assessed by: "Most of the published business news does not surprise me at all." Response categories cover $1=$ complete approval to $6=$ complete contradiction.

[C] Miscalibration is tested by $90 \%$ probability performance forecasts of home indices: "Please estimate the development of the S\&P 500 (EuroSTOXX 50 / SET, respectively) within the next month."

\begin{tabular}{|c|c|c|c|c|c|}
\hline \multirow{3}{*}{\multicolumn{2}{|c|}{$\begin{array}{c}\text { Evidence for male } \\
\text { overconfidence? }\end{array}$}} & \multicolumn{4}{|c|}{$\mathrm{H}_{\mathrm{o}}$ : no gender difference ${ }^{1}$} \\
\hline & & USA & GER & ITA & THA \\
\hline & & 0 & O & 1 9 & \\
\hline \multirow[t]{2}{*}{ [A] } & Management & $2.67 \quad 2.75$ & $3.13 \quad 3.00$ & $2.81 \quad 3.30$ & $3.09 \quad 3.22$ \\
\hline & performance & $-0.046(0.964)$ & $-0.587(0.557)$ & $-2.000 * *(0.046)$ & $-0.879(0.380)$ \\
\hline \multirow[t]{2}{*}{ [B] } & News novelty & $3.08 \quad 3.53$ & $3.23 \quad 3.42$ & $3.41 \quad 3.71$ & $3.06 \quad 3.19$ \\
\hline & & $-1.418(0.156)$ & $-1.338(0.181)$ & $-1.142(0.253)$ & $-0.855(0.392)$ \\
\hline \multirow[t]{2}{*}{ [C] } & Home index & $17.6 \quad 21.5$ & $22.2 \quad 37.4$ & $11.8 \quad 8.4$ & 15.616 .3 \\
\hline & range in $\%^{2}$ & $-1.331(0.183)$ & $-1.934 *(0.053)$ & $-0.894(0.371)$ & $-0.251(0.802)$ \\
\hline
\end{tabular}

1 The table gives the mean value for male and female asset managers in comparison as well as the z-value of the respective Mann-Whitney $U$ test regarding gender specific differences in the four displayed countries. The p-value is given in parentheses. Asterisks refer to level of significance: $* 10 \%, * * 5 \%, * * * 1 \%$.

2 Index ranges are given in percentages; calculated by relating the difference of maximum and minimum level estimations to the actual level 


\begin{tabular}{|c|c|c|c|c|c|c|}
\hline \multirow{3}{*}{$\begin{array}{l}\text { Overconfidence controlled for } \\
\quad \text { personal characteristics } \\
\text { Female }\end{array}$} & \multicolumn{6}{|c|}{ Ordered PROBIT / TOBIT regressions ${ }^{1}$} \\
\hline & \multicolumn{2}{|c|}{$\begin{array}{c}\text { Worse assessment } \\
\text { of management } \\
\text { performance }\end{array}$} & \multicolumn{2}{|c|}{$\begin{array}{c}\text { Higher surprise } \\
\text { about business } \\
\text { news }\end{array}$} & \multicolumn{2}{|c|}{$\begin{array}{c}\text { Broader } \\
\text { home index } \\
\text { estimation }\end{array}$} \\
\hline & 0.068 & $(0.347)$ & 0.077 & $(0.271)$ & -0.399 & $(0.699)$ \\
\hline Older & 0.076 & $(0.273)$ & -0.113 & $(0.100)$ & 0.465 & $(0.645)$ \\
\hline More experienced & $-0.102 *$ & $(0.074)$ & 0.031 & $(0.578)$ & -0.640 & $(0.420)$ \\
\hline Married & 0.027 & $(0.653)$ & -0.019 & $(0.755)$ & 1.158 & $(0.164)$ \\
\hline Better educated & 0.023 & $(0.799)$ & 0.044 & $(0.601)$ & 1.591 & $(0.207)$ \\
\hline Higher position & -0.061 & $(0.467)$ & -0.009 & $(0.916)$ & -0.808 & $(0.510)$ \\
\hline More personal AuM & 0.011 & $(0.802)$ & -0.017 & $(0.690)$ & $1.082 *$ & $(\mathbf{0 . 0 8 7})$ \\
\hline More working hours & $-0.147 * * *$ & $(0.005)$ & 0.049 & $(0.343)$ & 1.051 & $(0.157)$ \\
\hline Other than mutual fund type & 0.021 & $(0.730)$ & 0.093 & $(0.128)$ & 0.885 & $(0.298)$ \\
\hline Rather bond investment fund & 0.007 & $(0.904)$ & 0.032 & $(0.593)$ & -0.345 & $(0.688)$ \\
\hline Lower tracking error allowed & 0.064 & $(0.170)$ & 0.030 & $(0.508)$ & -0.359 & $(0.580)$ \\
\hline Dummy GER & $0.447 * * *$ & $(\mathbf{0 . 0 0 3 )}$ & $-0.271 *$ & $(0.066)$ & $3.888 *$ & $(\mathbf{0 . 0 8 7})$ \\
\hline Dummy ITA & 0.157 & $(0.447)$ & -0.018 & $(0.930)$ & $-6.035^{*}$ & $(\mathbf{0 . 0 5 5})$ \\
\hline Dummy THA & 0.223 & $(0.236)$ & $-0.607 * * *$ & $(0.001)$ & 0.778 & $(0.777)$ \\
\hline Constant & \multicolumn{2}{|l|}{-} & \multicolumn{2}{|l|}{-} & 5.279 & $(0.413)$ \\
\hline $\begin{array}{l}\text { LR statistic } \\
\text { (Pseudo-) } \mathrm{R}^{2}\end{array}$ & \multicolumn{2}{|c|}{$\begin{array}{c}42.35^{* * *} * \\
0.04\end{array}$} & \multicolumn{2}{|c|}{$\begin{array}{c}20.92 \\
0.02\end{array}$} & \multicolumn{2}{|c|}{$\begin{array}{c}- \\
0.10\end{array}$} \\
\hline
\end{tabular}

1 The table shows the coefficients of the ordered PROBIT regressions for the first two dependant variables, testing for unrealistically positive self-evaluation and control illusion, and a TOBIT regression for the home index estimation range that addresses miscalibration, respectively. P-values are given in parentheses. Asterisks refer to level of significance: $* 10 \%, * * 5 \%, * * * 1 \%$. Further explanations of the three dependent variables can be found in Table 5, information about the control variables is given in Table 2. Country dummies for Germany, Italy and Thailand are binary coded. 
Tournament behavior is assessed by requesting the surveyed asset managers to imagine that - apart from any fund's restriction - their portfolio's performance differs from its benchmark near the end of the period. We then address two scenarios as follows: "If my portfolio has outperformed (underperformed, respectively in the second scenario) its benchmark so far, I would...

[A] not change my strategy,

[B] increase the relative risk level to become a top performer,

[C] decrease the relative risk level to lock in the performance."

\begin{tabular}{|c|c|c|c|c|}
\hline \multirow{2}{*}{$\begin{array}{c}\text { Gender differences } \\
\text { in tournament be- } \\
\text { havior }\end{array}$} & \multicolumn{4}{|c|}{$\mathrm{H}_{\mathrm{o}}$ : no gender difference ${ }^{1}$} \\
\hline & 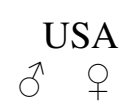 & $\begin{array}{l}\text { GER } \\
0 \quad q\end{array}$ & $\begin{array}{l}\text { ITA } \\
0^{\lambda} \text { q }\end{array}$ & $\begin{array}{l}\text { THA } \\
0^{\lambda}+\end{array}$ \\
\hline
\end{tabular}

Scenario 1: If the portfolio has outperformed its benchmark so far...

[A] Change instead
of keeping
$20.0 \quad 5.9$
$33.6 \quad 45.8$
$61.4 \quad 81.8$
$38.8 \quad 60.4$
strategy
$-1.409(0.159)$
$-1.191(0.234)$
$-1.781 *(0.075)$
$-2.393 * *(0.017)$
$0.8 \quad 0.0$
$\begin{array}{ll}0.9 & 0.0\end{array}$
$\begin{array}{ll}4.8 & 0.0\end{array}$
$7.5 \quad 5.2$
$-0.390(0.696)$
$-0.415(0.678)$
$-0.694(0.488)$
$0.09(0.93)$
[C] Decrease risk

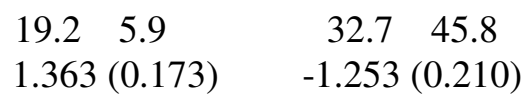
$56.6 \quad 81.8$
$31.3 \quad 55.2$
$-1.924 *(0.054)$
$-2.625 * * *(0.009)$

[B] Increase risk

Scenario 2: If the portfolio has underperformed its benchmark so far ...

[A] Change instead

\begin{tabular}{|c|c|c|c|c|}
\hline $\begin{array}{l}\text { of keeping } \\
\text { strategy }\end{array}$ & $\begin{array}{cc}15.4 & 24.6 \\
-0.852 & (0.394)\end{array}$ & $\begin{array}{cc}30.4 & 37.5 \\
0.714 & (0.475)\end{array}$ & $\begin{array}{rr}41.0 & 50.0 \\
-0.758 & (0.449)\end{array}$ & $\begin{array}{cc}47.0 & 74.1 \\
\mathbf{- 3 . 0 6 5} * * * & (\mathbf{0 . 0 0 2})\end{array}$ \\
\hline ncrease risk & $\begin{array}{cc}12.3 & 11.8 \\
-0.069 & (0.945)\end{array}$ & $\begin{array}{cc}7.9 & 20.8 \\
\mathbf{- 1 . 9 4 0} & (\mathbf{0 . 0 5 2})\end{array}$ & $\begin{array}{cc}18.1 & 36.4 \\
-1.587 & (0.113)\end{array}$ & $\begin{array}{cc}25.8 & 58.6 \\
\mathbf{- 3 . 6 6 8} * * * & (\mathbf{0 . 0 0 0})\end{array}$ \\
\hline & $\begin{array}{c}3.111 .8 \\
\mathbf{- 1 . 6 9 2} *(\mathbf{0 . 0 9 1})\end{array}$ & $\begin{array}{cc}22.5 & 16.7 \\
-0.326 & (0.744)\end{array}$ & $\begin{array}{rr}22.9 & 13.6 \\
-0.498 & (0.619)\end{array}$ & $\begin{array}{rr}21.2 & 15.5 \\
-0.766 & (0.444)\end{array}$ \\
\hline
\end{tabular}

1 The table gives mean percentages for male and female asset managers in comparison as well as the $\mathrm{z}$-value of the respective Mann-Whitney U test regarding gender specific differences in the four displayed countries. The p-value is given in parentheses. Asterisks refer to level of significance: * $10 \%, * * 5 \%$, *** $1 \%$. 
TABLE 8. Tournament behavior in a multivariate framework

\begin{tabular}{|c|c|c|c|c|c|}
\hline \multirow{3}{*}{$\begin{array}{c}\text { Tournament behavior } \\
\text { controlled for personal } \\
\text { characteristics }\end{array}$} & \multicolumn{5}{|c|}{ Binary PROBIT regressions ${ }^{1}$} \\
\hline & \multicolumn{2}{|c|}{ Scenario 1: Outperformance } & \multicolumn{3}{|c|}{ Scenario 2: Underperformance } \\
\hline & $\begin{array}{l}\text { Change } \\
\text { strategy }\end{array}$ & Decrease risk & $\begin{array}{l}\text { Change } \\
\text { strategy }\end{array}$ & $\begin{array}{l}\text { Increase } \\
\text { risk }\end{array}$ & $\begin{array}{l}\text { Decrease } \\
\text { risk }\end{array}$ \\
\hline Female & $\begin{array}{c}\mathbf{0 . 1 8 1} * * \\
(0.043)\end{array}$ & $\begin{array}{c}0.199 * * \\
(0.028)\end{array}$ & $\begin{array}{c}\mathbf{0 . 1 9 6} * * \\
(0.027)\end{array}$ & $\begin{array}{l}0.294 * * * \\
(0.004)\end{array}$ & $\begin{array}{c}0.058 \\
(0.632)\end{array}$ \\
\hline Older & $\begin{array}{l}-0.135 \\
(0.147)\end{array}$ & $\begin{array}{l}-0.131 \\
(0.163)\end{array}$ & $\begin{array}{l}-0.122 \\
(0.196)\end{array}$ & $\begin{array}{l}-0.102 \\
(0.397)\end{array}$ & $\begin{array}{l}-0.087 \\
(0.451)\end{array}$ \\
\hline More experienced & $\begin{array}{c}0.079 \\
(0.288)\end{array}$ & $\begin{array}{l}0.088 \\
(0.243)\end{array}$ & $\begin{array}{l}0.035 \\
(0.647)\end{array}$ & $\begin{array}{c}0.032 \\
(0.743)\end{array}$ & $\begin{array}{c}0.080 \\
(0.396)\end{array}$ \\
\hline Married & $\begin{array}{l}-0.006 \\
(0.937)\end{array}$ & $\begin{array}{l}-0.025 \\
(0.742)\end{array}$ & $\begin{array}{l}-0.049 \\
(0.531)\end{array}$ & $\begin{array}{l}-0.091 \\
(0.343)\end{array}$ & $\begin{array}{l}-0.029 \\
(0.769)\end{array}$ \\
\hline Better educated & $\begin{array}{l}-0.075 \\
(0.502)\end{array}$ & $\begin{array}{l}-0.085 \\
(0.450)\end{array}$ & $\begin{array}{l}-0.138 \\
(0.226)\end{array}$ & $\begin{array}{c}-0.282 * * \\
(0.031)\end{array}$ & $\begin{array}{c}0.142 \\
(0.396)\end{array}$ \\
\hline Higher position & $\begin{array}{l}-0.068 \\
(0.534)\end{array}$ & $\begin{array}{l}-0.087 \\
(0.439)\end{array}$ & $\begin{array}{c}0.028 \\
(0.801)\end{array}$ & $\begin{array}{l}-0.059 \\
(0.666)\end{array}$ & $\begin{array}{c}0.096 \\
(0.495)\end{array}$ \\
\hline More personal AuM & $\begin{array}{l}-0.081 \\
(0.155)\end{array}$ & $\begin{array}{l}-0.082 \\
(0.156)\end{array}$ & $\begin{array}{c}-0.119 * * \\
(0.040)\end{array}$ & $\begin{array}{c}-0.145 * * \\
(0.042)\end{array}$ & $\begin{array}{l}-0.109 \\
(0.150)\end{array}$ \\
\hline More working hours & $\begin{array}{c}0.034 \\
(0.612)\end{array}$ & $\begin{array}{c}0.013 \\
(0.853)\end{array}$ & $\begin{array}{c}0.080 \\
(0.235)\end{array}$ & $\begin{array}{c}0.175 * * \\
(0.039)\end{array}$ & $\begin{array}{l}-0.028 \\
(0.742)\end{array}$ \\
\hline $\begin{array}{l}\text { Other than mutual fund } \\
\text { type }\end{array}$ & $\begin{array}{l}-0.013 \\
(0.868)\end{array}$ & $\begin{array}{l}-0.030 \\
(0.704)\end{array}$ & $\begin{array}{l}-0.096 \\
(0.227)\end{array}$ & $\begin{array}{l}-0.061 \\
(0.535)\end{array}$ & $\begin{array}{l}-0.069 \\
(0.490)\end{array}$ \\
\hline $\begin{array}{l}\text { Rather bond investment } \\
\text { fund }\end{array}$ & $\begin{array}{c}0.181 \\
(0.017)\end{array}$ & $\begin{array}{c}0.193 * * \\
(0.012)\end{array}$ & $\begin{array}{c}0.072 \\
(0.350)\end{array}$ & $\begin{array}{c}0.088 \\
(0.341)\end{array}$ & $\begin{array}{c}0.054 \\
(0.598)\end{array}$ \\
\hline $\begin{array}{l}\text { Lower tracking } \\
\text { error allowed }\end{array}$ & $\begin{array}{c}0.060 \\
(0.304)\end{array}$ & $\begin{array}{c}0.049 \\
(0.409)\end{array}$ & $\begin{array}{c}0.080 \\
(0.179)\end{array}$ & $\begin{array}{c}0.118 \\
(0.104)\end{array}$ & $\begin{array}{c}0.021 \\
(0.772)\end{array}$ \\
\hline Dummy GER & $\begin{array}{c}0.590 * * * \\
(0.003)\end{array}$ & $\begin{array}{c}0.589 * * * \\
(0.003)\end{array}$ & $\begin{array}{c}0.301 \\
(0.141)\end{array}$ & $\begin{array}{c}-0.131 \\
(0.595)\end{array}$ & $\begin{array}{c}0.899 * * * * \\
(0.004)\end{array}$ \\
\hline Dummy ITA & $\begin{array}{c}1.259 * * * \\
(0.000)\end{array}$ & $\begin{array}{c}1.202 * * * \\
(0.000)\end{array}$ & $\begin{array}{c}\mathbf{0 . 5 6 1} * * \\
(0.035)\end{array}$ & $\begin{array}{l}0.568 * \\
(0.063)\end{array}$ & $\begin{array}{l}0.662 * \\
(0.079)\end{array}$ \\
\hline Dummy THA & $\begin{array}{c}0.699 * * * \\
(0.004)\end{array}$ & $\begin{array}{c}0.518 * * \\
(0.036)\end{array}$ & $\begin{array}{c}1.056 * * * \\
(0.000)\end{array}$ & $\begin{array}{c}1.070 * * * \\
(0.000)\end{array}$ & $\begin{array}{c}1.170 * * * \\
(0.009)\end{array}$ \\
\hline Constant & $\begin{array}{l}-0.968 * \\
(0.099)\end{array}$ & $\begin{array}{l}-0.801 \\
(0.177)\end{array}$ & $\begin{array}{l}-0.495 \\
(0.404)\end{array}$ & $\begin{array}{l}-0.693 \\
(0.323)\end{array}$ & $\begin{array}{c}-1.852 * * \\
(0.026)\end{array}$ \\
\hline $\begin{array}{l}\text { LR statistic } \\
\text { (McFadden) } R^{2}\end{array}$ & $\begin{array}{c}65.11 * * * \\
0.12\end{array}$ & $\begin{array}{c}61.65^{* * * *} \\
0.11\end{array}$ & $\begin{array}{c}69.66^{* * * *} \\
0.13\end{array}$ & $\begin{array}{c}84.60 * * * \\
0.22\end{array}$ & $\begin{array}{c}26.48 * * \\
0.08\end{array}$ \\
\hline
\end{tabular}

The table gives the coefficients of the binary PROBIT regressions with p-values in parentheses (dependent Variables are binary coded). Asterisks refer to level of significance: *10\%, ** 5\%, *** $1 \%$. Further explanations of the five binary dependent variables can be found in Table 7, information about the control variables is given in Table 2. Country dummies for Germany, Italy and Thailand are binary coded. 